\title{
婦人科標本中に認められたいわゆる ヘマトイジン結晶様物質の検討
}

\author{
岐阜県立多治見病院 ${ }^{1)}$, 名古屋大学医学部第 1 病理学教室 ${ }^{21}$ \\ 名古屋市立大学医学部臨床検査 医学教室 ${ }^{3}$ \\ 岡田 基 ${ }^{1)}$ 松井 明男 ${ }^{1)}$ 米沢千佳子1) 伊藤 雅文 ${ }^{2)}$ \\ 柴田 偉雄 ${ }^{3)}$
}

\begin{abstract}
婦人科標本中に認められたいわゆるへマトイジン結晶様物質（以下へマトイジン様結晶と略す） について，4 年 6 力月の間に当院を受診した 41,274 人，標本件数 116,360 件を対象に検討した. 35 人（45 件）にへマトイジン様結晶を認めた. 35 例の年齢分布は 24 歳から 52 歳（平均 38.7 歳） であった。疾患内訳は, 腔部ビラン 17 名, 妊娠 7 名, 切迫流産 4 名, 異形成 2 名, 上皮内癌 1 名 であった。へマトイジン様結晶の出現頻度は，子宮胵部擦過で $0.05 \%$, 子宮頸管擦過で $0.04 \%$ で あった。結晶の出現様相は，パパニコロー染色で黄金色ないし黄褐色調に染色され，ロゼット状配 列，樹枝状配列を呈する集塊が主体で，一部は散在性に楕円形結晶として出現した。大きさは 1 $341.5 \mu$ であった。大多数の結晶は，組織球や好中球からなる炎症細胞集塊中に認められた。特殊 染色ではPAS 染色が陽性を呈したが，ほかの粘液染色，鉄染色，ビリルビン染色は陰性であり， 免疫染色ではフェリチン， S-100 蛋白，EMA 陰性であった．以上の所見から婦人科標本中に認め られたへマトイジン様結晶は，へマトイジンとは異なる物質で，へモグロビン系の色素ではないと 考えられた。
\end{abstract}

Key words : Uterine material-Hematoidin Crystalline substance-Cytology

\section{I. はじめに}

生体内で産生され細胞診検体に出現する結晶は,

Examination of hematoidin crystalline substance found in gynecological preparations

Hajime OKADA ${ }^{1)}$, C.T., I.A.C., Akio MATSUI ${ }^{1)}$, C.T., J.S.

C., Chikako YONEZAWA ${ }^{1)}$, C.T., I.A.C., Masafumi ITO'), M.

D., Hideo SHIBATA ${ }^{3)}$, M.D.

${ }^{1)}$ Clinical Laboratory, Prefectural Hospital at Tajimi, Gifu

${ }^{2}$ First Department of Pathology, Nagoya University School of Medicine

${ }^{3}$ Department of Clinical Laboratory Medicine, Nagoya City University Medical School

論文別刷請求先 $\$ 507$ 岐皁県多治見市前烟町 5 の 161 岐 阜県立多治見病院中央臨床検查部 岡田 基

平成 5 年 11 月 22 日受付

平成 5 年 12 月 18 日受理
種々のものが知られており，特に尿中には各種の結晶 が出現する。婦人科標本中にみられる結晶について は，現在までいくつかの報告1 4)がみられ，これらの 結晶は Hematoidin 結晶と呼ばれている。黄金色ない し黄褐色を呈し，ロゼット様の配列を主体とする結晶 で，子宮頸部擦過標本中に認められ，妊婦や炎症性疾 患に多く出現し, 異形成や悪性疾患ではほとんど認め られないことが知られている。この結晶の化学的組成 や発生機序については一定の見解はみられない. 今回 われわれは，へマトイジン様結晶について，その性状 と疾患との関連を検索する目的で，婦人科材料中の擦 過部位別出現率, 臨床的背景, 結晶の各種染色所見な らびに理化学反応について検討した。 


\section{II. 材料および方法}

1988 年 6 月から 1992 年 11 月までの 4 年 6 力月の 間に，当院で細胞診検査を行った 41,274 人，標本件 数 116,360 件の婦人科検体標本を対象とした. 子宮胵 部, 子宮頸管, 子宮体部内膜, 断端, 腟壁, 外陰なら びに䏽分泌物の, 部位別の結晶出現率を求め, 結晶が 認められた症例の臨床所見, 標本中の出現様式につい

て検討した.

ヘマトイジン様結晶がみられた標本を $1 \%$ 塩酸 70\%エチルアルコールにて脱色後，1）PAS 染色，2） 唾液消化試験＋PAS 染色，3）アルシアン青染色，4） ベルリン青染色，5）スタインのヨード染色5)，6）ホ ールのビリルビン染色 ${ }^{6)}$ ，7）ラルフのへモグロビン染 色 ${ }^{6)}$, 8) AFIPのリポフスチン染色6), ABC 法を用い た 9）フェリチン，10）S-100蛋白，11）EMAに対す る免疫染色を行った。

結晶の溶解を，1）95\%アルコール，2）1\%塩酸 $70 \%$ アルコール，3）キシロール，4） $3 \%$ 酢酸水，5） $10 \%$ 水酸化カリウム水溶液の各溶液で試みた。

偏光フィルターを用い, 結晶の観察を行った.

\section{III. 結 果}

\section{1. 出現頻度}

へマトイジン様結晶の出現頻度は, 41,274 人中 35 人 $(0.05 \%)$ であり，標本件数 116,360 件中 45 件 (0.04\%) であった。検体採取部位別では，子宮胵部 擦過 27 件, 子宮頸管擦過 18 件でみられたが, 子宮体 部内膜擦過, 断端擦過, 胵壁擦過, 外陰擦過, 胵分泌 物中の標本にはへマトイジン様結晶は認められなかっ た(表 1 ).

\section{2. ヘマトイジン様結晶の出現様相}

ヘマトイジン様結晶は, パパニコロー染色では黄金 色ないし黄褐色を呈し，ロゼット状配列（写真 1 ）, 樹枝状配列（写真 2) が主体の集団としてみられ，一 部は楕円形から類円形の弧在性結晶であった。結晶の

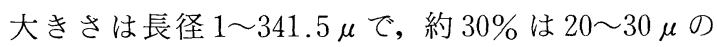
範囲であった。ロゼット状配列の集団と樹枝状配列の 集団の出現頻度は 100 個の集団のうち，ロゼット状配 列の結晶は 45 個 $(45 \%)$ ，樹枝状配列を示す結晶は 55 個 $(55 \%)$ であった。大多数のへマトイジン様結 晶は多数の好中球や組織球に取り囲まれていた。ま
表 1 検体採取部位別出現率

\begin{tabular}{l|rrr}
\hline \hline & 標本件数 & 出現件数 & 出現率 \\
\hline 子宮腔部擦過 & 62,748 & 27 & $0.04 \%$ \\
子宮頸管擦過 & 34,846 & 18 & $0.05 \%$ \\
子宮内膜擦過 & 2,726 & 0 & $0 \%$ \\
断 端 擦過 & 15,590 & 0 & $0 \%$ \\
胵 壁 擦過 & 186 & 0 & $0 \%$ \\
外 陰 擦過 & 182 & 0 & $0 \%$ \\
腔 分 泌 物 & 82 & 0 & $0 \%$ \\
\hline
\end{tabular}

た，組織球内に貧食された結晶も認められた（写真 3 ).

\section{3. 臨床所見および細胞所見}

35 例中の年齢分布は 24 歳から 52 歳で, 平均 38.7 歳であった。臨床所見では䐋部ビラン 17 名, 妊娠 7 名, 切迫流産 4 名, 中等度異形成 2 名, 上皮内癌 1 名 であった. 45 件の標本中炎症所見として多数の好中 球の出現が認められたものは 39 件, 背景に出血が認 められたものは 3 件であった (表 2 ). 月経第 1 日目 から数えてへマトイジン様結晶が認められた日数は 16 名中早い人で 8 日目, 遅い人で 33 日目であった。

\section{4. 特殊染色所見および理化学反応}

ヘマトイジン様結晶はPAS 染色（写真 4) と唾液 消化試験+PAS 染色で陽性であったが, 他の染色で はすべて陰性（写真 $5 〜 7$ ）であった. 理化学反応で は検索したすべての溶液に不溶であった（表 3 ）。

\section{5. 偏光顕微鏡観察所見}

偏光フィルターを用いた観察では, 脂肪球のような マルタクロスや緑色の発光は認められず, 暗色で特定 所見は得られなかった。

\section{IV. 考察}

細胞診断学の分野でへマトイジン結晶の記載は 1974 年に Hollander ら ${ }^{7)}$ が発表しているが, 多くの 報告はみられない. 子宮頸部擦過標本中におけるへマ トイジン様結晶の出現率（表 4 ）は報告者により異な るが, 今回の検索では子宮胵部擦過および子宮頸管擦 過を合わせると $0.08 \%$ であり，ほかの報告者と比べ ると比較的少ない出現率であった。しかし Hollander $ら^{7)}$, Capaldo $5^{8)}$, Zaharopoulos $ら^{11)}$, 井筒 $5^{4)} 4$ 人の報告数を総計すると総件数 391,203 件で結晶の出 現者数は 235 人であり, 結晶の出現率は $0.06 \%$ とな り当院の出現率と近似値となる。へマトイジン様結晶 
表 2 結晶が認められた症例における細胞所見および臨床的背景

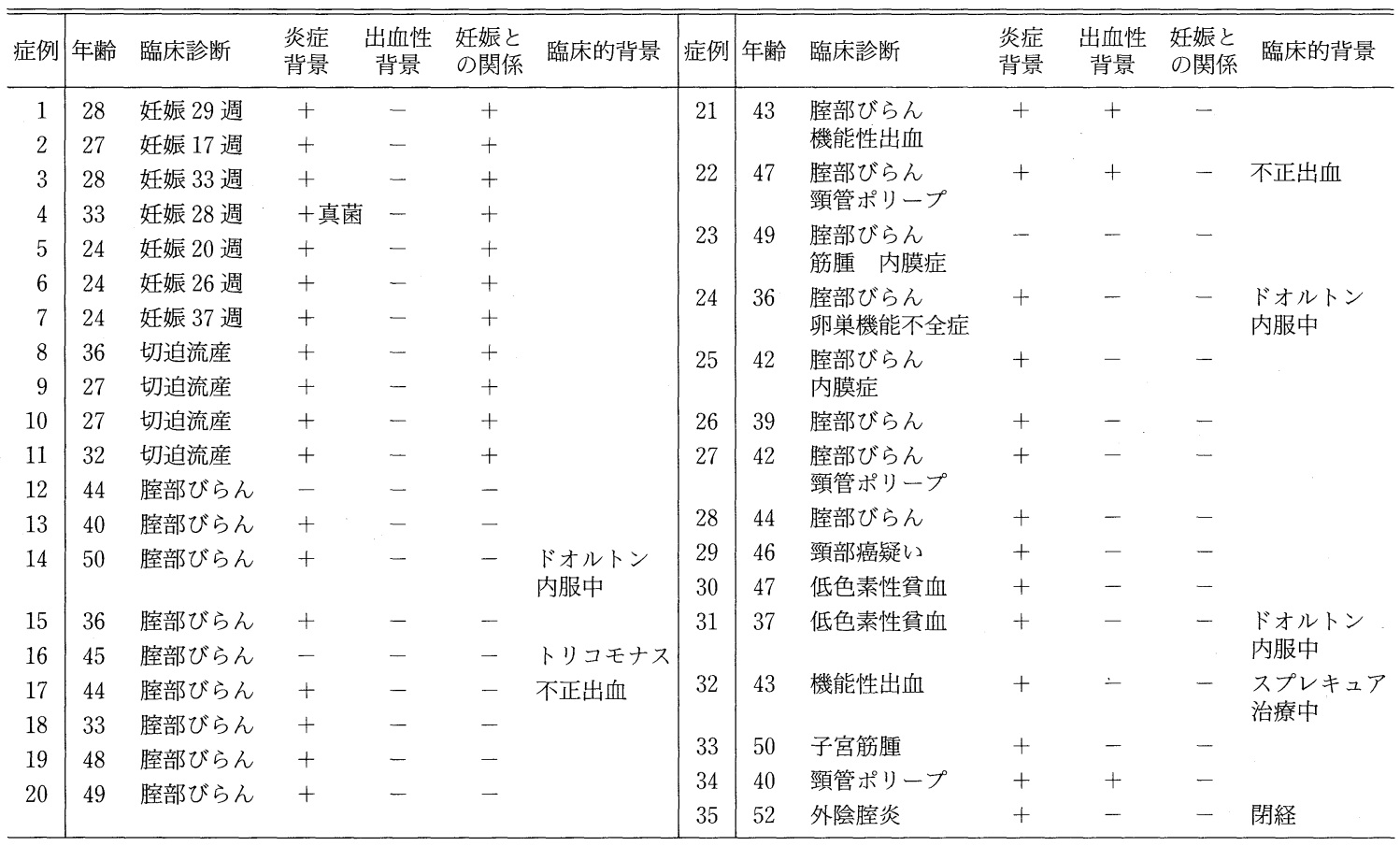

表 3 ヘマトイジン様結晶の特殊染色所見および理化学反応

\begin{tabular}{lc|lcc}
\hline \hline \multicolumn{1}{c}{ 染 色 名 } & 反応結果 & \multicolumn{1}{|c}{ 染 色 } & 名 & 反応結果 \\
\hline PAS & + & フェリチン & - \\
唾液消化試験+PAS & + & EMA & - \\
アルシアンブルー & - & S-100 蛋白 & - \\
ベルリンブルー & - & $95 \%$ アルコール & 不溶 \\
スタインのヨード法 & - & $1 \%$ 塩酸, $70 \%$ アルコール & 不溶 \\
ホールのビリルビン染色法 & - & キシロール & 不溶 \\
ラルフのヘモグロビン染色法 & - & $3 \%$ 酢酸 & 不溶 \\
AFIPのリボフスチン染色法 & - & $10 \%$ 水酸化カリウム & 不溶 \\
\hline
\end{tabular}

表 4 各施設におけるへマトイジン様結晶の出現率

\begin{tabular}{c|c|r|rrr}
\hline \hline 年 & 報 告 者 & 受診者数 & $\begin{array}{r}\text { ヘマトイジンの出現例数 } \\
(\mathrm{A})\end{array}$ & $\begin{array}{c}\text { 妊娠者数 } \\
(\mathrm{B})\end{array}$ & $(\mathrm{B}) /(\mathrm{A}) \times 100$ \\
\hline 1974 & Hollander など & 250,000 & $36(0.01 \%)$ & 25 & $69.4 \%$ \\
1979 & Capaldo など & 2.640 & $27(1.02 \%)$ & 22 & $81.5 \%$ \\
1980 & " & 3,160 & $40(1.27 \%)$ & 36 & $90.0 \%$ \\
1985 & Zaharopoulosなど & 35,000 & $111(0.32 \%)$ & 97 & $87.4 \%$ \\
1987 & 井䇢など & 100,403 & $21(0.02 \%)$ & 7 & $33.3 \%$ \\
1992 & 当施設 & 41,274 & $35(0.08 \%)$ & 11 & $31.4 \%$ \\
\hline
\end{tabular}

はわれわれの検討した標本では 1 枚に 1 カ所のみの集 団しか認められないものもあり，特に小型の結晶が多 数の炎症細胞にマスクされている場合には認めづら く, 弱拡大では見落としやすく, スクリーニング時に
ある程度結晶の出現を意識して標本を観察しなければ 見落とす可能性もある.

へマトイジン様結晶の妊娠との関連については井筒 らの報告4では必ずしも関連性があるとは考えられな 
いと報告しておりわれわれも 35 例中 24 例は妊娠に 関係なく認められた。しかし妊婦に多くみられる傾向 があり, 妊娠に付䯣した条件がへマトイジン様結晶の 生成に関与している可能性は考えられた。

へモグロビン系の色素は, 赤血球が崩壊し中のへモ グロビンの分解産物でへモジデリン，へマトイジン， 胆汁色素がある。へモジデリンは黄褐色の色素で鉄を 含有し, へマトイジンは黄色の色素で鉄を含有しない 物質である.へマトイジン結晶の化学的性質について はV Virchow ら ${ }^{10)}$, Zaharopoulos ら ${ }^{9)}$, 井筒 ら ${ }^{4)}$ は鉄 を含まない物質であると報告し, Lignac ら ${ }^{1)}$, Richi ら ${ }^{2)}$ はビリルビンと同一物質であると述べている。し かしわれわれが行った分析結果では鉄やビリルビンは 証明されず，へモジデリンやへマトイジン，胆汁色素 とは異なる物質で, へモグロビン系の色素ではないと 思われる.へマトイジン結晶とわれわれが検討したへ マトイジン様結晶との鑑別点は，へマトイジン結晶は 黄褐色または赤褐色の顆粒状, 菱形状, 針状などの形 態をとるが，本結晶は無色であり，菱形や針状の形状 は認められない。また，へマトイジン結晶はアルカリ に溶けやすく, アルコール，エーテルに難溶である が5)，われわれが検討したへマトイジン様結晶はアル カリに不溶であり, 両者の鑑別は形状, 色調, アルカ リ溶液に溶解か不溶解かの点が鑑別に役立つと考えら れる。 今回のわれわれの検索綕果はZ Zaharopoulos $ら^{11)}$, 井筒ら ${ }^{4)}$ の特殊染色結果と同様であり, 井筒 ら ${ }^{4)}$ はこの結晶は血液中の蛋白質の結晶である可能性 が強いと述べているが，われわれの検討した結果から も蛋白質の結晶が考えられた。しかしへマトイジン様 結晶が婦人科材料以外には, 自験例では耳下腺腫瘍の 穿刺材料抢よび喀痰に 1 例ずつ認められたのみで尿, 胸水, 腹水などには認められていない。このことは結 晶の生成に子宮腟部や子宮頸管の生理的環境が関与し ていると推測される。結晶析出の原因にはイオン強度

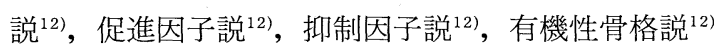
など種々の報告があるが，今回の検索では明らかにし 得なかった。

ヘマトイジン様結晶と炎症細胞との関連について は, 炎症細胞が結晶をとり巻くようにみられ, その貧 食もみられることから, 二次的に好中球や組織球が異 物と認識して異物肉芽を形成したと考えられた。

結晶の色調については，パパニコロー染色では黄金 色から黄褐色調であるが，1\% 塩酸 70\% エチルアル コールあるいは $80 \%$ エチルアルコールで脱色し，脱
色した結晶に再度パパニコロー染色を行ったところ， オレンジ G-6 の色素で再染色され黄金色となること， また $10 \%$ 水酸化カリウム水溶液でも脱色され, 再度 パパニコロー染色を行うとオレンジ G-6の色素で黄 金色に染色されることから，黄金色から黄褐の色調は 結晶自体の色調ではなく，オレンジ G-6 と EA 50 の 染色液により着色されたものであり, 本来の結晶は無 色無偏光性結晶であると考えられた。へマトイジン様 結晶の生化学的組成および成因の解析には超微形態的 観察やX線解析法が必要と考えられた。

本論文の要旨は，第 12 回日本細胞学会東海連合会総会にて発 表した。

\section{Summary}

In respect to the hematoidin crystalline substance found in gynecological preparations, we examined 41,274 patients of Gifu Prefectural Tajimi Hospital during the 1988 to 1992 period and 116,360 preparations taken from them. As a result, we found hematoidin crystalline in 45 preparations taken from 35 patients. These 35 patients then ranged in age from 24 to 52 years old (average 38.7 years old). On clinical observation and diagnosis, it was confirmed that 17 had vaginal erosion, 7 were pregnant, 4 suffered from threatened abortion, 2 had dysplasia and 1 had carcinoma in situ. The hematoidin crystalline appeared at a ratio of $0.05 \%$ in vaginal smears and at a ratio of $0.05 \%$ in cervical smears. The substance was observed to be gold or yellowish brown crystals on Papanicolaou staining, appearing mainly as agglomerates arranged like rosettes or twigs in most cases, and as elliptical crystals in some cases. These crystals ranged in size from 1 to $341.5 \mu$. Most crystals were found in cellular agglomerates consisting of histiocytes and neutrophils. The substances were positive with the PAS staining method, negative with mucin staining out of PAS, iron and bilirubin staining methods. By means of imuno-histochemical staining, the substances showed no positive reaction with ferritin, S-100 protein or EMA antisera. From the above observations, we considered the hematoidin crystalline substance in gynecological preparations to be different from the hematoidin substance or pigment of the hemoglobin system.

\section{文献}

1) Lignac, G.O.E. : Uber das Hamatoidin und Gallenfar- 
bstoff, Virchows Archiv (Pathol. Anat.), $243: 273 \sim$ 279, 1923.

2) Richi, A.R., Bumstead, J.H. : On the identity of hematoidin and billirubin, Bull Johns Hopkins Hosp., 36 : 225 232, 1925.

3) Robbins, S.L. : Pathology, Third edition, p.425, W.B. Sanders, Philadelphia, 1967.

4）井筒俊彦・他：子宮頸部擦過細胞診標本に認められたい わゆるへマトイジン結晶とその意義, 日臨細胞誌, 28(4) : 501〜 504, 1989.

5）高浜素秀 - 他：臨床検查講座 12 巻, 病理学, pp. 253 254, 医歯薬出版株式会社, 東京, 1973.

6) Leeg・Luna 編：AFIP 病理組織標本染色法マニアル, pp. 153 233, 清至書院，東京, 1982.

7) Hollander, D.H., Gupta, P.K. : Hematoidin cockleburrs in cervicovaginal smears, Acta. Cytol., $18: 268 \sim$ 269, 1974.

8) Capaldo, G., Legolvan, D.P., Dramczyk, J.E. : Hematoidin crystal in cervicovaginal smears: review of 27 cases in one year, Acta. Cytol., $27: 237$ 〜240, 1983.

9) Zaharopoulos, P., Wong, J.Y., Keagy, N. : Hematoidin crystal in cervicovaginal smears: Report of two cases, Acta. Cytol., 29: 1029 1034, 1985.

10) Virchow, R. : Die Pathologischen pigmente, Virchow Arch, $1: 379 \sim 404,1847$.

11) Zaharopoulos, P., Wong, J.Y. Edmonston, et al. : Crystallinbodies in cervicovaginal smears: A cytochemial and immunochemical study, Acta. Cytol., $29:$ 1035 1042, 1985.

12）岡井美恵子・他：尿中 2,8-dihydroxy-adenine（DHA） 結晶が契機となり無症候性 APRT 欠損症（遺伝子型 $\mathrm{APRT} * \mathrm{~J} / \mathrm{APRT} * \mathrm{QO})$ と診断することができた 1 例, 医学検查, 41 (9) : 1493〜1497, 1992. 


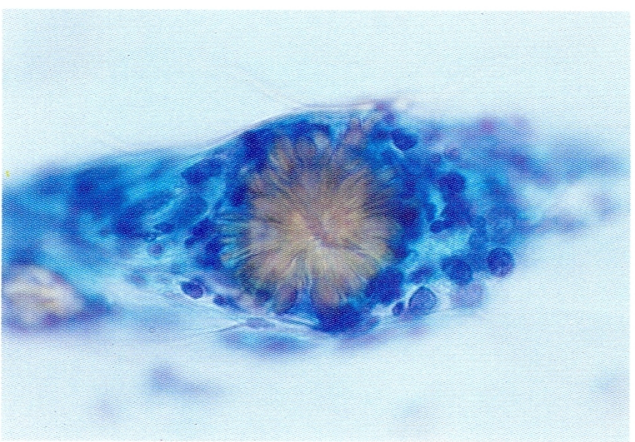

写真 1 ロゼット状配列を示すへマトイジン様結晶 (Pap. 染色, $\times 1,000)$

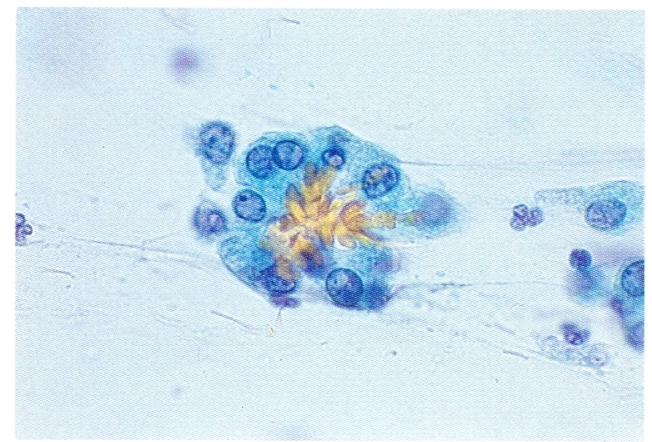

写真 3 組織球内に貪食されたへマトイジン様結晶 (Pap. 染色, $\times 1,000$ )

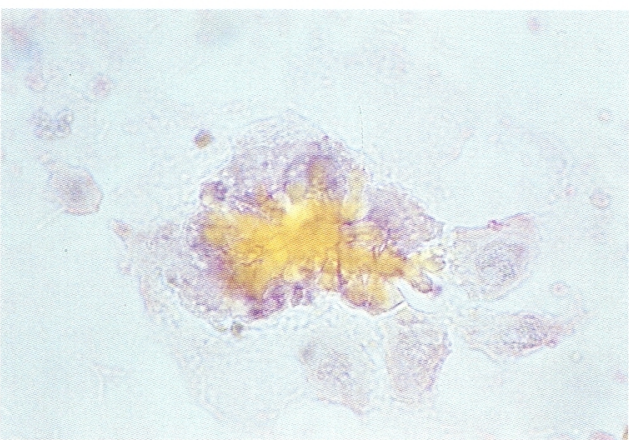

写真 5 ホールのビリルビン染色では陰性であった ヘマトイジン様結晶 $(\times 1,000)$

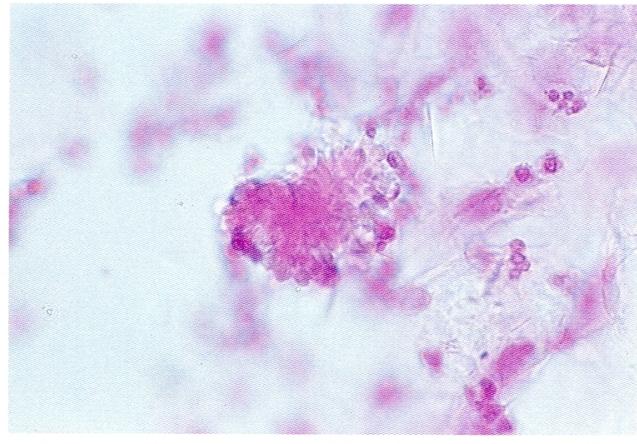

写真 7 ラルフのヘモグロビン染色では陰性であった ヘマトイジン様結晶 $(\times 1,000)$

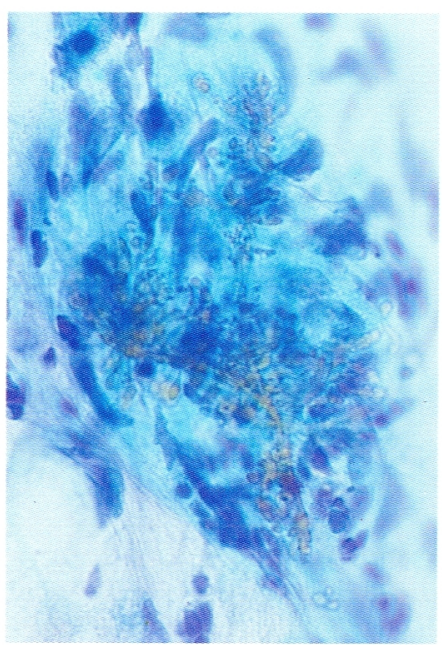

写真 2 樹枝状配列を示すへマトイジン 様結晶 (Pap. 染色, $\times 1,000)$

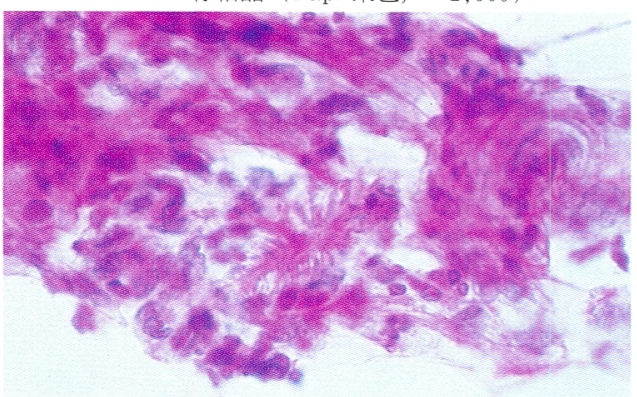

写真 4 PAS 染色が陽性を呈したへマトイジン様結晶 $(\times 1,000)$

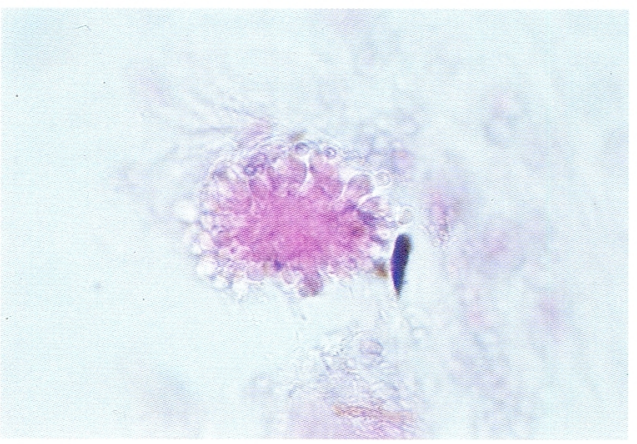

写真 6 ベルリン青染色では陰性であったへマトイ ジン様結晶 $(\times 1,000)$ 